\title{
Üniversite Öğrencilerinin Ulusal ve Uluslararası Barışa İlişkin Görüşleri*
}

\author{
Yasemin KARAMAN-KEPENEKCI ${ }^{* *}$
}

ÖZ. Bu çalışmanın amacı üniversite öğrencilerinin ulusal ve uluslararası barışa ilişkin görüşlerini ortaya koymaktır. Araştırmanın katılımcılarını 2006-2007 Eğitim-Öğretim Yılı'nda Ankara Üniversitesi Eğitim Bilimleri Fakültesi Sosyal Bilgileri Öğretmenliğgi programına devam eden, vatandaşlık bilgisi dersini almış ve öğretmen olduğunda da vatandaşlık eğitimi verecek ve araştırmaya katılmaya istekli altmış üniversite öğrencisi oluşturmuştur. Katılımcıların görüşleri açık uçlu sorulardan oluşan bir anket ile toplanmış ve yazılı olarak verdikleri cevapları betimsel analiz yöntemi ile analiz edilmiştir. Araştırmanın sonuçlarına göre katılımcılar genellikle ulusal barıştan, ulusal birlik ve huzuru; uluslararası barıştan uluslar arasındaki ilişkilerin iyileştirilmesini anlamakta ve ulusal barışın vatandaştan, devletten ve diğer devletlerden kaynaklanan nedenlerle engellendiğini düşünmektedir. Uluslararası barışının sağlanamamasını ise büyük ölçüde devletlerin dünya kaynaklarını elde etme yolunda giriştikleri rekabete bağlamışlardır. Katılımcılardan bazısı genel olarak üniversite öğrencilerini ulusal ve uluslararası barışa duyarlı bulmakla birlikte, bu görüşte olmayan katılımcılar da bulunmaktadır. Katılımcılar, üniversite öğrencilerini barışa daha duyarlı hale getirmek üzere özellikle üniversitelerde, içinde öğrencilerin de olduğu barış ile ilgili proje ve diğer etkinliklerin düzenlemesini önermişlerdir.

Anahtar Sözcükler: Ulusal barış, uluslararası barış, barış hakk1, barış eğitimi, üniversite öğrencisi

*Bu çalışma 14-16 Haziran 2007 tarihlerinde düzenlenen 2. İstanbul Demokrasi ve Küresel Güvenlik Konferensı'nda sunulan bildirinin genişletilmiş halidir.

**Doç. Dr. Ankara Üniversitesi Eğitim Bilimleri Fakültesi Tel: 0312363 33 50/3005

E-posta: ykepenekci@hotmail.com; karaman.kepenekci@gmail.com 


\section{ÖZET}

İnsanın olduğu her yerde ve tarihin her döneminde şiddet olayları olmuştur. Şiddet içeren savaşlar, toplumun mantığına ve insanın doğasına aykırı olmakla birlikte, insanlık tarihi kadar eskidir. Mitolojiye göre, Zeus'un oğlu Ares, Olimpos'ta şiddet içeren uygulamaları ile tanınmıştı. Yine geçmişte yapılan savaşlar şiddetin en büyük boyutta yaşandığına dair örneklerle doludur. Ne yazık ki, şiddet olgusu her dönemde olduğu gibi günümüz dünyasında da varlığını sürdürmektedir. Ailede, okulda, işyerinde ve medyada (hatta oyuncak sektöründe) şiddetin değişik türlerine ve öğelerine tanık olunmaktadır (Karaman-Kepenekci, 2004).

Savaşlar gerek bireyin gerekse toplumun yaşamını kaybetmesine yol açtığı için toplumun var oluş nedenine aykırı olmasına rağmen, insanlar savaşlara yaşam ve geçim koşullarının baskısı altında yeni kaynaklar arama amacıyla başvurmuşlardır (Sencer, 1986). Ancak galibi kim ve hangi toplum olursa olsun, savaşların sonuçları hiçbir taraf için iyi değildir. Ölümler, sakatlanmalar, anne, baba ve yakınlarını kaybeden insanlar, öksüz ve yetim çocuklar; açlık, ekonomik kriz ve savaşların acı sonuçlarıdır. Bu sonuçların giderilmesi ise çok uzun yıllar almaktadır.

Alpkaya'ya (2001) göre, uluslararası hukukta "barış" 20. yüzyıla kadar "savaşmama durumu" olarak anlaşılmış ve uluslararası hukuk öğretisinde yakın döneme kadar savaş hukuku ve barış hukuku iki ana eksen olarak yer almıştır. Bunun anlamı, savaşın uluslararası hukukta meşru sayılmasıdır. Bu meşruiyetin dayanağı, uluslararası hukukta kural koyan ve yaptırım uygulayan merkezi bir otoritenin bulunmamasıdır. Zamanla insanlar, kendi kaynakları ile kendilerine yetebilecek duruma gelerek savaştan kaçmışlar ve barış1 üstün bir amaç olarak benimsemişlerdir (Sencer, 1986). Uluslar arasında her türlü savaşın ortadan kalkması ve evrensel barışın kurulması fikri 19. yüzyılın sonlarında ortaya çıkmıştır (Alpkaya, 2001).

Birinci Dünya Savaşı'nı takip eden dönemde "sürekli ve evrensel barışı ve uluslararası güvenliği sağlamak" amaciyla kurulan Milletler Cemiyeti dünyayı ikinci bir toplumsal savaşa sürüklenmekten kurtaramamıştır. İkinci Dünya Savaşı'ndan sonra, aralarında Türkiye'nin bulunduğu 51 ülke bir araya gelerek Birleşmiş Milletler örgütünü kurmuşlardır. Birleşmiş Milletler'in kuruluş antlaşmasında, daha önce yaşanan iki dünya savaşının önemli etkisi görülür. 1945'te imzalanan Birleşmiş Milletler Antlaşması'nda, dünya barışı için öncelikle temel hak ve özgürlüklere saygının sağlanması gerektiği dile getirilmiştir.

Aslında, toplumsal düzen kurallarından olan hukuk kurallarının amacı, toplumda huzur, güven ve barış1 sağlamaktır (Gözübüyük, 1993). Bu yüzden 
günümüzdeki tüm ulusal ve uluslararası hukuk kurallarının doğrudan veya dolaylı olarak barış hakkını düzenlediği söylenebilir. Birleşmiş Milletler Antlaşması'nın yanında, diğer bazı hukuksal metinlerde de doğrudan barış hakkını ilgilendiren ifadelere rastlanabilir. Kișisel ve Siyasal Haklar Uluslararası Sözleşmesi'nin (1966), 20. maddesinde geçen "Her türlü savaş propagandası hukuk tarafindan yasaklanır. Ayrımcilı̆ga, kin ve nefrete veya şiddete tahrik eden herhangi bir ulusal, ırksal veya dinsel düşmanliğın savunulması hukuk tarafindan yasaklanır." hükmü bu duruma örnek olarak gösterilebilir. Birleşmiş Milletler uluslararası barış ve güvenliğin korunması ile ilgili dört maddeden oluşan Halkların Barış Hakkı Bildirgesi'ni yayınlamıştır. Bildirge'de "Gezegenimizin halklarının barış hakkı kutsaldır." (m. 1) ilkesi öngörülmüştür.

Teknolojik ve bilimsel ilerlemelerin yarattı̆̆ dayanışma hakları olarak anılan hakları ortaya çıkarmıştır (Kaboğlu, 1996) Dayanışma haklarının ortak özelliği, diğer tüm insan haklarının ortak özelliği olan yaşam hakkını ortak payda olarak almasıdır. Dayanışma hakları, tüm insan haklarının da korunması için ortak gözetim, işbirliği ve dayanışmayı gerektirmesine karşın, niteliğinden kaynaklı olarak işbirliği ve dayanışma özelliği belirgin bir biçimde ortada olan haklardır. Bu hakların gerçekleşmesi için yalnızca devletin müdahalesi yeterli değildir, birey ve grupların da çabası gerekir (Gülmez, 2001). Barış hakkı, dayanışma hakları başlığı altında yer almaktadır.

Tüm temel hakların ve özgürlüklerin var olabilmeleri ve insanlar tarafından tam anlamıyla kullanılabilmeleri için o toplumda öncelikle barışın olması gerekir (TİHAK, 2000). Kuşkusuz, savaş ortamında insan haklarına saygıdan söz edilemez. Savaş hali, savaş tehlikesinin baş göstermesi, ayaklanma, iç kargaşa gibi bunalım dönemlerinin devletin ve toplumun güvenliği bakımından tehlike yarattığına şüphe yoktur. Bu tehlikenin ortadan kaldırılması hızlı kararların alınmasını gerektirir. Ne var ki alınan önlemler kişilerin haklarını özgürlükleri daha da kısıtlayıcı nitelikte olmaktadır. Bireylerin bazı fedakârlıklara katlanmaları istenebilir, onlara normal yaşamda söz konusu olmayan bazı yükümlülükler yüklenebilir (Kapani, 1981).

Yıllarca savaşmış bir halka komutanlık etmiş olan Atatürk her zaman barışın önemine inanmıştır. Atatürk'ün "Yurtta barış dünyada barış" sözünden, onun düşünce yapısında barışın önemli bir yer tuttuğu anlaşılabilir. Atatürk'e göre evrensel barış ile uluslararası denge birbirinden ayrılması güç, iç içe girmiş iki kavramdır (Türkiye İş Bankası, 1992). Gerçekten de, evrensel barış, dünya ile uluslar arasında gerçekçi ve eşitlikçi bir denge kurulduğunda ulaşllabilecek bir sonuçtur. Türkiye'nin iç ve dış 
politikasında, Atatürk'ün vurguladığı barıș ilkesi, önemli ve belirleyici bir ilke olmaya devam etmektedir. Ne yazık ki, bu ilkeye rağmen Türkiye'de barışın dış ve iç tehdit olmak üzere iki şekilde tehlikeye girdiği görülmektedir (Doğan, 2002). Türkiye üzerinde emelleri olan ülkeler, Türkiye'ye doğrudan savaş açmak yerine, ülkeyi güçsüz ve çaresiz bırakacak yöntemleri uygulamaktadır. Bunun yanında, ülkemizi içten yıkmaya çalışan ve aşırı hareketler olarak nitelenebilen bölücü, ayrımcı, ayrılıkçı ve ideolojik özelliklere sahip olan iç tehdit unsurlarının hepsinin ortak amacı, mevcut rejimi yıkarak kendi görüşleri doğrultusunda yeni bir düzen kurmaktır (Doğan, 2002).

Herkesin özlemini duyduğu iç ve dış barışın sağlanabilmesi için, barışa inanan ve barışın sağlanması için mücadele edebilecek insanların yetiştirilmesi gerekir. Bu da kısaca "barış eğitimi" ile sağlanmaktadır. Barış eğitimi konusunda yapılmış birçok çalışma (Reardon, 1988; Harris, 2004; Haavelsrud, 2004; Köylü, 2004; Carter, 2004; Wintersteiner, 2004; Synott, 2005; Spence ve Makuwira, 2005; Aktan-Kerem ve Kamaraj, 2007; MansurSertel, 2007; Oral, 2007; Pembecioğlu-Öcel; 2007) bulunmaktadır. MansurSertel'e göre (2007) barış eğitiminin temel hedefi, bireyi çatışmaları yaratıcı, yapıcı ve barışçıl şekillerde çözecek becerilerle donatmaktır. Bu durum, bireylerin sorunlarına yapıcı çözümleri kendilerinin bulmalarına yardımcı olmakla sağlanmaktadır. Barış eğitimi, bireyin farkındalığını ve davranış becerilerini artırarak, kalabalık grupları barışçıl topluluklara dönüştürmeyi amaçlamaktadır. Asıl hedef toplum da olsa, değişim önce bireyde başlamaktadır. Öğrencilerin, ulusal ve uluslar arası barışa ilişkin sahip oldukları görüşlerinin ve mevcut farkındalık düzeylerinin ortaya konması, onlara yönelik olarak düzenlenecek barış eğitimi çabalarının etkililiğini artıracaktır. Türkiye'deki öğrencilerin ve özellikle üniversite öğrencilerinin barışa ilişkin görüşlerini ortaya koyan herhangi bir araştırmaya rastlanmamıştır.

$\mathrm{Bu}$ çalışmanın amacı üniversite öğrencilerinin ulusal ve uluslararası barışa ilişkin görüşlerini ortaya koymaktır. Araştırmanın katılımcılarını, vatandaşlık bilgisi dersini almış ve öğretmen olduğunda da vatandaşlık eğitimi verecek Ankara Üniversitesi Eğitim Bilimleri Fakültesi Sosyal Bilgileri Öğretmenliği programına devam eden ve araştırmaya katılmaya istekli altmış üniversite öğrencisi oluşturmuş̧tur.

Katılımcıların görüşleri araştırmacı tarafindan geliştirilmiş açık uçlu sorulardan oluşan bir anket ile toplanmıştır. Anketle katılımcılardan;

(1) Atatürk'ün "Yurtta Sulh Cihanda Sulh" deyişinin anlamına, (2) ulusal ve uluslararası barışın sağlanmasının engellerine, (3) genel olarak 
üniversite öğrencilerinin barışa duyarlılıklarına, (4) üniversite öğrencilerinin ulusal ve uluslararası barışa duyarlı1ı̆̆ını artırmak için yapılabileceklere ve son olarak, (5) gelecekte öğretmen olduklarında ulusal ve uluslararası barışa duyarlı öğrenciler yetiştirmek için yapabilecekleri sınıf içi ve sınıf dışı etkinliklere ilişkin görüşlerini yazılı olarak belirtmeleri istenmiştir. Katılımcıların görüşleri bir nitel araştırma yöntemi olan "betimsel analiz" yöntemi ile analiz edilmiştir.

Çalışmanın sonunda üniversite öğrencilerinin ulusal barış kavramından ulusal birlik ve beraberliği anladıkları ve dolayısıyla barışı geniş bir şekilde yorumladıkları ortaya çıkmaktadır. Barış eğitiminin başarıya ulaşmasının ön koşullarından biri insanların önce kendilerine saygı duymalarını sağlamaktır (Branson ve Purta, 1982). Bu araştırmada sadece bir katılımcı bu gerçeğin farkına varabilmiştir. $\mathrm{Bu}$ durumda üniversite gençlerinin önemli bir bölümünün barışın kişinin kendine olan saygı ve güvenden geçtiğini bilmediği söylenebilir. Yine bir katılımcı barışı hiçbir zaman gerçekleşmeyecek ideal bir durum olarak tanımlamış ve savaşız bir dünya düşünemediğini ifade etmiştir. Bu katılımcı barışın gerçekleşeceğine ilişkin olumsuz bir tutum içindedir. Barışa ilişkin olumlu tutum taşıma ile barışın yaşama geçirilmesini sağlama arasında doğru bir orantı olduğu söylenebilir; çünkü davranışlar önemli ölçüde tutumlardan etkilenmektedir (Bloom, 1995). Öyleyse barışı gerçekleştirmede yapılacak ilk iş tüm üniversite öğrencilerinin Türkiye'de ve dünyada barışın gerçekleşebileceğine inanmalarını sağlamaktır.

Katılımcılar ulusal barışın, Doğan'ın (2002) da belirttiği iç ve dış tehdit unsurları yüzünden zarar gördüğünü düşünmektedir. Barış eğitimi ile öğrencilerin korkularını tanımalarına ve etrafında olup bitenlerin farkına varmalarına çalışılır. Bu durumda katılımcıların barışın engellerinin farkında olduğu düşünülebilir. Katılımcılar ulusal ve uluslararası barışın vatandaştan, devletten ve diğer devletten kaynaklanan engelleri ile hukuk sistemi içinde mücadele etmenin gerekli olduğuna inanmakla birlikte, hiçbir katılımc1 barışın sağlanmasında uluslararası örgütlerin yeterince etkili olduğunu düşünmemektedir.

Genel olarak üniversite öğrencilerini barışa karşı duyarlı bulmayan katılımcılar bu durumu insanların aşırı bireyselleşmesi ve bencilleşmesi, olayları ve olguları eleştirmeden, olduğu gibi kabul etmesi ve hatta kendilerinin şiddet içeren eylemlerde bulunması gibi iletişim, çatışma çözme ve eleştirel düşünme becerilerindeki yetersizliklere bağlamaktadır. MansurSertel'in (2007) belirttiği gibi etkili bir barış eğitimi ile öğrencilerin öfke yönetimi, çatışma çözme, iletişim, eleştirel düşünme ve empati gibi yetenekleri geliştirilmeye çalışılır. Üniversite öğrencilerinin bu becerilerin 
geliştirecek eğitimler almaya ihtiyacının bulunduğu açıktır. Katılımcıların üniversite öğrencilerini barışa daha duyarlı hale getirmek için getirdikleri önerilerin çoğunluğu aslında üniversite öğrencilerine verilecek insan hakları eğitimine işaret etmektedir. Katılımcılar, ileride öğretmen olduklarında sınıf içi ve dışında öğrencilere tartışma, münazara, drama gibi yöntemleri kullanarak uygulayacakları etkinliklerle ve konu ile ilgili yerlere geziler düzenlemek, araştırmalar yaptırmak, ilgilileri okula konferans vermek üzere davet etmek, film ve belgeseller izletmek suretiyle barışa duyarlı öğrenciler yetiştirmeyi hedeflemektedir. 


\title{
Opinions of University Students towards National and International Peace*
}

\author{
Yasemin KARAMAN-KEPENEKCI $\dot{I}^{* *}$
}

\begin{abstract}
The aim of the research is to examine the opinions of Turkish university students about national and international peace. The participants of the study are sixty volunteer university students from Ankara University Faculty of Educational Sciences, Department of Social Sciences Education and who have taken the citizenship course in the 2006-2007 academic years and will deliver citizenship education in elementary schools in the future. Participants' opinions about peace were gathered through open-ended questions. Descriptive analysis, which is a qualitative research method, was used to analyze the views of social sciences teacher trainees. The results showed that the participants generally interpret national peace as national unity and peace of mind; international peace as betterment of international relations, and believe that barriers to national peace are rooted in reasons related to citizens, the government, and the other governments. They associated the reason for not establishing international peace largely to the competition that states are in to gain the world sources. Some of the participants find university students sensitive towards national and international peace while there are those who do not find them so sensitive. The participants suggested that activities and projects involving students be held in universities to make them more sensitive.
\end{abstract}

Keywords: National peace, international peace, right to peace, peace education, university student

\footnotetext{
* An earlier draft of this article was presented at the $2^{\text {nd }}$ Istanbul Conference on Democracy and Global Security, Turkey, June 14-16, 2007.

** Assoc. Prof. Dr. Ankara University Faculty of Educational Sciences

Tel: 0312 3633350/3005 E-mail: ykepenekci@hotmail.com; karaman.kepenekci@gmail.com
} 


\section{INTRODUCTION}

Acts of violence have always existed in history where there are human beings. Violent wards are as old as humanity no matter how they are incongruous with public common sense and human nature. In mythology, Zeus's son Ares was known for his violent acts in Olympos. The wars in the past are full of examples indicating the highest levels of violence. Unfortunately, the concept of violence persists today as it did in any period. Many types and elements of violence can be encountered in the family, schools, offices and media (even in the toy sector) (Karaman-Kepenekci, 2004).

Although wars are contrary to the existence of society since they lead to loss of lives of individuals and societies, humans resorted to wars in search of new sources under the pressure of survival and conditions for livelihood (Sencer, 1986). Yet, however or whichever society turns out to be victorious, the consequences of wars do not benefit either party. Deaths, casualties, people who lose their mothers, fathers, or loved ones, orphans, hunger, and economic crises are all bitter results of wars. It is not before many years that these consequences are repaired.

According to Alpkaya (2001), "peace" was interpreted as "the state of not being at war" in international law until the 20th century and the law of war and the law of peace were taken as two pivots in international law school until the recent era. This means that war is considered legal in international law. The grounds of this legality are the lack of a central authority to enact and enforce law in international law. In time, man escaped war by achieving self-sufficiency using their own sources and embraced peace as a superior aim (Sencer, 1986). Peace bears such meanings as a state of tranquility or quiet, freedom from civil disturbance, a state of security or order within a community provided by the law or customs, freedom from disquieting or oppressive thoughts or emotions, harmony in personal relations, a state or period of mutual concord between governments, a pact or agreement to end hostilities between those who have been at war or in a state of enmity (Alpkaya, 2001). The notion of abolishing any type of international war and establishing international peace emerged towards the end of the 19th century (Alpkaya, 2001).

Following the period of the First World War, the League of Nations, which was established for the purpose of "sustained universal peace and international safety", failed to prevent the world from going into a second communal war. After the Second World War, 51 countries, including Turkey, formed the United Nations organization. Significant impact of the 
previous world wars can be observed in the foundation treaty of the United Nations. In the United Nations Charter signed in 1945, the need for establishing primarily respect for fundamental rights and freedoms for world peace was stated.

Actually, the aim of legal rules which are social order rules is to establish tranquility, safety and peace in society (Gözübüyük, 1993). For this reason, it can be said that all national and international legal rules directly or indirectly regulate the right for peace. Besides the United Nations Charter, one can encounter some statements regarding the right for direct peace in some other legal texts. One example for this could be article no. 20 of the International Covenant on Civil and Political Rights (Adopted and opened for signature, ratification and accession by General Assembly resolution 2200A (XXI) of 16 December 1966, entry into force 23 March 1976) "Any propaganda for war shall be prohibited by law. Any advocacy of national, racial or religious hatred that constitutes incitement to discrimination, hostility or violence shall be prohibited by law." United Nations issued the Declaration on the Right of Peoples to Peace, which constitutes four articles, related to sustaining international peace and safety (Approved by General Assembly resolution $39 / 11$ of 12 November 1984). It is proclaimed in this document that "peoples of our planet have a sacred right to peace" (Article $1)$.

Various problems arising from technological and scientific advances led to solidarity rights to emerge (Kaboğlu, 1996). The common aspect of solidarity rights is that it covers the right to live as the shared element which is the common aspect of all other human rights. Although solidarity rights require common supervision, collectivity and solidarity to protect all human rights, collectivity and solidarity are distinctively clear rights due to their character. To realize these rights, the sole intervention of the government is not sufficient, but individual and group effort is necessary (Gülmez, 2001). The right to peace is under the main topic of solidarity rights.

For all fundamental rights and freedoms to exist and to be used fully, primarily there should be peace in that society (TIHAK, 2000). Undoubtedly, human rights are not a subject of discussion in war. Such crisis periods as war, an impending war, uprisal, or internal chaos undoubtedly risk the peace of the society and the government. Eliminating this danger requires fast decision making. However, precautions bear the nature of restricting individual rights. Individuals might be asked to compromise or take on certain responsibilities which may not be the case under normal circumstances (Kapani, 1981). 
Atatürk, who commanded the society who had been fighting for years, always believed in the significance of peace. From Atatürk's maxim "Peace in the country, peace in the world", we can discern that peace has an important place in his way of thought. According to Atatürk, universal peace and international balance are inseparable two concepts (Türkiye İş Bankası, 1992). In fact, universal peace is achievable when a realistic and egalitarian balance is established between the world and the nations. In the domestic and foreign policies of Turkey, the peace principle that Atatürk emphasized still continues to be a significant and determining principle. Unfortunately, despite this principle, it can be observed that peace in Turkey is threatened internally and externally both ways (Doğan, 2002). Countries with ambitions over Turkey pursue methods to weaken her and push her into hopelessness instead of declaring a direct war to Turkey. Besides this, the common aim of all the internal threat elements which can be described to be pulling down the country from inside and marginal movements which have such characteristics as separatism, discrimination, and ideology, are all aimed at creating a new order in line with their own views by de-establishing the existing regime (Doğan, 2002).

In order to establish internal and external peace as endeavored by all, people who believe in peace and who will fight to establish peace should be raised and this is possible through "peace education". There are a number of studies (Reardon, 1988; Harris, 2004; Haavelsrud, 2004; Köylü, 2004; Carter, 2004; Wintersteiner, 2004; Synott, 2005; Spence \& Makuwira, 2005; Aktan-Kerem \& Kamaraj, 2007; Mansur-Sertel, 2007; Oral, 2007; Pembecioğlu-Öcel; 2007) focused on peace education. According to Harris (2004), during this past century, there has been a growth in social concern about horrific forms of violence, like ecocide, genocide, modern warfare, ethnic hatred, racism, sexual abuse and domestic violence, and a corresponding growth in the field of peace education where educators, from early child care to adulthood, use their professional skills to warn fellow citizens about imminent dangers and advise them about paths to peace.

According to Mansur-Sertel (2007), the basic aim of peace education is to equip individuals with skills to solve conflict in creative, constructive and peaceful ways. This can be enabled by helping individuals to find constructive solutions themselves. Peace education aims to turn masses of groups into peaceful societies by raising individuals' awareness and increasing their behavioral skills. Even if the real aim may be the society, change starts in the individual first.

Establishing the views that students hold towards national and international peace and their current awareness level will increase the 
effectiveness of peace education efforts geared for them. No other study has been encountered to explain students' and particularly university students' opinions towards peace in Turkey.

\section{PURPOSE}

The aim of the research is to examine the opinions of Turkish university students about national and international peace.

\section{METHOD}

\section{Participants}

The participants of the study are sixty volunteer university students from Ankara University Faculty of Educational Sciences, Department of Social Sciences Education in Turkey who have taken citizenship course in the 2006-2007 academic years and will give citizenship education in elementary schools. The reason for selecting them from Ankara University is that Ankara University is one of the biggest universities in Turkey with a diversity of students from different socio-cultural and economic backgrounds.

\section{Instrument}

In order to collect data, a questionnaire form was developed by the researcher. The questionnaire consists of a list of questions under the following topics: the participants' opinions on; (1) the meaning of Ataturk's maxim "Peace at home, peace in the world", (2) barriers to establishing national and international peace, (3) university students' sensitivity toward peace in general, and (4) possible means to increase university students' sensitivity toward national and international peace. Finally, participant opinions on, (5) curricular and extracurricular activities that they can carry out when they become teachers to raise students who are sensitive towards national and international peace were asked.

The data for topics were sought through open-ended questions. The participants were asked to state their opinions on these questions in written form.

\section{Data Analysis}

Participant opinions were analyzed through 'descriptive analysis', which is a qualitative research method. To provide reliability of the research, ten questionnaires filled by the participants evaluated by another educational sciences expert and high consistency was noted implying a good reliability. 


\section{Limitations}

This study is limited to the opinions of Ankara University Faculty of Educational Sciences, Department of Social Sciences Education students who take the compulsory citizenship course in the 2006-2007 academic years towards national and international peace.

\section{FINDINGS}

\section{Participant opinions towards Ataturk's maxim "Peace at home peace in the world"}

Participants who would be primarily responsible for peace education when they became teachers were asked what Ataturk's maxim "Peace at home, peace in the world" reminded them of and were asked to state their opinions. It was observed that their responses could be grouped under two main categories. These were opinions regarding "peace at home" and those related to "peace in the world".

Participant understanding of peace at home generally denotes "the existence of national unity and tranquility". The following statements exemplify general views of the participants;

- It means all who live in our country's soil and breathe the same air are in unity, collectivity, solidarity and prosperity and move in unison for national interests.

- It means that people who live on the soil of this country are in unity and collectivity against all internal and external pressures.

- If there is no unity and collectivity at home, world peace will not mean anything for this country. There should not be separatist activities in the country. If this country is separated, it will be condemned to be eradicated from earth.

- It means that all citizens, regardless of their language, faith or race, live in peace and protection from separatist activities.

- It means all citizens exist on our country's soil in a spirit of kindred and endearment.

- It means each citizen contributing to carrying the world forward regardless of the view of world and kind of life.

Some participants interpret peace at home to mean "ownership of common values". Some examples of these views could be given as "It is a country in which citizens who know its history very well, own up to national 
values and respect others' rights and responsibilities live." and "It denotes citizens owning up to the common values which keep them in unity and living in peace on the country's soil with common consciousness."

Some participants stated that peace at home means "striving to resolve disagreements within the country through peaceful means".

One participant stated that the phrase peace at home means "primarily being at peace with oneself". This participant added that it meant "people who like themselves will love their country and will not want problems that are unbearable for the country".

Some participants defined peace at home from the viewpoint of "international relations". The statements below can exemplify these participants' views:

- It denotes building positive relations among countries, striving to find peaceful solutions within the framework of international law to problems or disagreements that may occur.

- It is a world where countries respect each others' existence.

- It means countries place more importance to peace in the world, not murdering the world or other people for its interests.

- People of various races and faiths live in the world. If we share this world, then we need to treat each other with respect and love. It means not going into conflict of interest with other countries' people and not oppressing them just because they are weaker.

- It means refraining from impinging the rights of other countries or invading their soil for the development of one's own country.

- It means countries leaving past conflicts in the past and forming friendships, finding common ground by coming to agreement even if their economic and political interests may clash.

- It means countries not acting out of interest but displaying peaceful attitude in external politics by observing the right to live and honor.

Some participants stated that Atatürk's words of peace at home meant "living in peace with all countries as long as there is no threat towards our country".

Some participants interpreted the idea of peace at home by relating it to peace within the homeland and stated that if peace is established in the country, then peace can be established in the world. They stated that "Those 
who wish peace within their own country will wish the same for the others." and "It means wishing the same for the rest of the countries as what one wishes onto their own country". Some participants stated the opposite of this idea and said that "If there is peace in the world, then countries can establish peace in their own country".

One participant stated that peace at home denoted "a state which cannot be established in any circumstances".

Participant opinions towards barriers to establishing national and international peace

The participants were then asked what the factors formed a barrier to establishing national and international peace. Participants' views on the barriers to national peace can be examined under three subtopics, which are citizen-related, state-related and other state- related barriers.

The following statements can illustrate participants' opinions towards citizen-related barriers to establishing national peace:

- People's remoteness from the sense of national unity,

- Individuals' lack of awareness of history,

- Cultural corruption,

- Individuals' low education level,

- Families raising their children with ideas of hostility, lack of understanding among people,

- Growth of selfishness in people and individualism,

- Political differences becoming more distinct among layers of society,

- Public being influenced by external provocations,

- Citizens being influenced by internal interest groups,

- Individuals' false conviction that all personal interests are rights,

- Individuals' disrespect for each other's rights and responsibilities,

- The existence of some people and groups who are trying to spread their ideas through conflict and fights instead of democratic means,

- Those who are in economic difficulties sometimes trying to seek their rights through the wrong means. 
Participant opinions about state-related barriers to establishing peace could be categorized as below:

- The state disrespecting individuals' rights and responsibilities,

- Wrong state policies,

- Governors' dependence on their political status and putting their own interests above those of the country,

- Lack of decisive fight against internal and external threats by the governors of states,

- Not realizing economic progress in the country, economic inequality.

Participant responses to the other state-related barriers to national peace can be exemplified with their statements that "instigation of ethnic and religious separatism as parallel to the wishes of imperialist states and creating hostility among people living together" and "instillation of hatred and grudge among citizens by external powers who do not wish people of the country to progress".

Participant opinions towards barriers to establishing international peace can be categorized as below:

- Strong imperialist states pursuing policies that fit their own interests, striving towards taking over the underground and aboveground national sources in the world and not valuing humans in this respect,

- Powers wishing to dominate the world and competing for this purpose,

- Countries' ambition to gain superiority over each other,

- Capitalism,

- Unequal distribution of world sources,

- States' neutrality to creating solutions to problems,

- Fast increase in population,

- Fast consumption,

- Lacks of democratic govern in countries.

Finally, one participant stated that barriers to national and international peace were "the existence of individuals and groups who benefit from war and money being more important than anything else in today's world". 


\section{Participant opinions towards university students' sensitivity of towards peace}

The participants who were themselves university students were asked their opinions on university students' general sensitivity toward national and international peace. Their responses were categorized as "sensitive", "partially sensitive" and "insensitive (indifferent)".

Participants who thought that university students were "sensitive" toward national peace stated this in the following statements:

- We are a people who went through a war where much blood was shed such as the War of Independence in our history. As the children of such a people, we believe in the importance of national peace.

- It was not easy for us to establish the Republic. We are aware of the value of our country and peace in our country.

- The young of different places and cultures may reside together in universities and they say that this is richness.

- I love my country. I am happy to live here. I want to live in my country without conflict and wars. And I want my children to live in my country in peace, too.

Participants who thought that university students are "partially sensitive" toward national peace stated their reasons in the following way:

- There are friends who strive to keep peace and support such efforts but those who are not sensitive to these are more in number.

- Those who are against peace are as many as those who support it. And everyone is sure about the correctness of their own view. They do not respect the others' views.

- Some students embrace the idea of unity and that Turkish people are friends of all peoples as Atatürk stated, but for some students, personal interests bear more importance than national interests.

- I think that a large portion of university students are becoming more individualistic and more insensitive towards peace in the country.

- I think that some university students believe in the direction of the ideas that have been imposed on them without questioning them. This badly affects national unity and national peace. 
Participants who believe that university students are "insensitive (indifferent)" towards national peace state the following:

- The national peace sensitivity which Atatürk tried to establish does not exist now. Most university students are unaware of the significance of national peace.

- I believe that we are a generation who have grown up with a tabloid type culture, depoliticized people and thus we are indifferent towards national peace:

- Students most of the times stay non-reactive towards decision that damage national peace and events that threaten peace. Sometimes they are used as tools in many games planned to damage national peace and actively participate in separatist activities.

- Student movements occurring in our university are indicators of how indifferent students are toward national peace.

- Even the activities for peace are not peaceful.

Participants who think that university students are "sensitive" toward international peace can be exemplified by the following statements:

- University students are aware that developed technologies create such weapons that can bring the end of the world in any kind of a large scale war.

- University students are aware of the games that are played in the world.

- University students show reaction against the war in Iraq and what the USA is doing.

Participants who think that university students are "partially sensitive" toward international peace explained their opinions in the following way:

- They know the importance of international peace but they do not know how to establish this.

- I think that this varies from one university to another. The ones who are in more preferred universities are more sensitive.

- In order to grasp international peace and to implement it, first of all national peace needs to be established. Those who are not sensitive toward national peace are not sensitive toward international peace, either. 
- I do not think that a significant part of university youth has a general idea about other countries' internal dynamics and international relations, which are necessary for sensitivity toward international peace.

Participants who think that university students are "insensitive (indifferent)" toward international peace stated their opinions in the following way:

- The young think that this is politicians' job.

- There are those who are extremely individualistic and cannot fully grasp the importance of peace.

- I do not think that university youth are sensitive toward foreign events. They are only interested in domestic events.

- The conflict of interest among countries has reached such a point that I do not think any one cares about world peace.

Participant opinions towards provisions to increase university students' sensitivity toward national and international peace

The participants were asked what the possible means to increase university students' sensitivity towards national and international peace and their responses were examined under two categories, which are "provisions to increase sensitivity toward national peace" and "provisions to increase sensitivity toward international peace".

Participant opinions towards provisions to increase university students' sensitivity toward national peace can be stated as the following;

- $\quad$ First and foremost, love for the country should be instilled but I think this sense of love can be given during primary school period rather than at university level.

- Any educational means in and out of class should be utilized in order for university students to grasp that all are humans despite differences, that our people is in real sense an inseparable whole.

- There should be projects that university students can participate in for the prevention of threats against national peace.

- Peace workshops should be organized to be undertaken by university students only. 
- Discussions on how people in history lived for years in friendship and peace in this country, and then how this state was damaged and the wars we endured should be held with examples in classes.

- $\quad$ Students should be provided with activities which should not be limited to class hours so that students are more aware of their own people.

- Students should be provided with training which will equip them with skills to solve their problems through legal and democratic means.

- The first way to make not only university youth but everyone sensitive towards national peace is to have critical and objective media.

Participant opinions towards provisions to increase university students' sensitivity towards international peace are the following:

- The damage that international wars caused in the past and in the present should be shown in classes.

- Instructors should include this subject in their courses to show that even those students who shout out the slogans of anti-imperialism are tools of imperialism itself.

- International student exchange programs need to be further developed and their scope should be broadened.

- The first provisions should be toward national peace sensitivity.

- I cannot even imagine international peace since there will be conflict all the time.

To increase sensitivity toward both national and international peace, participants suggest that conferences, panels and symposiums need to be organized in universities.

Participant opinions towards their provisions to raise students who are sensitive towards national and international peace when they become teachers

The final question asked to participants was the kind of curricular and extracurricular activities that they would set up when they became teachers in the future to raise students who would be sensitive toward national and international peace. The participants stated that they would implement the following curricular activities for this purpose: 
- I will prepare classroom activities that will foster student discussion on the topics that I determine for them to become aware of the importance of peace and be aware of the threats that might threaten it.

- I will ask them to bring cut-outs from the newspapers on war related news to discuss them or I will post the news pieces on the class bulletin for all to read.

- By creating an environment where they can defend their ideas and listen to those of each others and set up debates where they can discuss different means of establishing peace.

- I will have students watch films and documentaries in class about the negative effects of war.

- By using drama method in class, I will enable them to grasp what kind of consequences may occur as a result of treating individuals in hostility or friendship.

The extracurricular activities that the participants are planning to implement are the following:

- I will take students to related seminars or conferences or I will invite state or public organization members who are working in the relevant field to give a speech in the school.

- By arranging the school administration to organize tours to places where the First World War and the War of Independence took place, I will try to make students see the places where the war actually took place and thus make them feel the negative impact of war.

- Excursions to the museums and memorials that are close to the school may be arranged.

- I will organize trips to places with different cultures.

- For them to grasp the importance that Atatürk placed on peace, I will assign research homework for them to learn his life and the way he thought.

- I will assign them to research the contributions of international organizations to world peace.

- I will encourage students to become pen friends with their peers in other countries. 


\section{DISCUSSION and CONCLUSION}

As Harris states, peace is a broader concept than just non-existence of war and encompasses respect for all beings (quoted in Mansur-Sertel 2007). In this research which illustrated university students' views on national and international peace, national peace emerged to denote national unity and collectivity and thus students interpret peace in broad terms. One of the prerequisites of success in peace education is to achieve instilling selfrespect in people (Branson \& Purta, 1982). In this study, only one participant was aware this fact. Therefore, it can be said that a significant amount of university students are unaware that peace denotes personal self-respect and self-esteem. One participant described peace as a non-achievable ideal and stated that $\mathrm{s} /$ he could not think of a world without war. This participant has a negative attitude towards the realization of peace. It can be said that there is a direct relationship between a positive attitude towards peace and putting peace into practice in real life. The reason is that behaviors are greatly influenced by attitudes (Bloom, 1995). Therefore, the first thing to undertake for the realization of peace is to enable university students to believe that peace can be become a reality in Turkey and in the world.

Participants think that national peace is damaged because of internal and external threat elements, as Doğan (2002) states. Peace education aims to help students become familiar with their fears and become aware of the events around them. In this case, it can be said that the participants are aware of the barriers to peace. Participants believe that it is necessary to fight the citizen-related, state-related or other state-related barriers to national and international peace within the legal system, however, they do not think that international organizations are sufficient to effectively establish peace.

In general, participants who do not think that university students are sensitive towards peace associate this to such insufficiency in their skills at communication, conflict resolution and critical thinking as extreme individualism in people and selfishness, acceptance of events and concepts without questioning and taking part in violent acts themselves. As MansurSertel (2007) states, through effective peace education, student skills at anger management, conflict resolution, communication, critical thinking, and empathy are developed. It is clear that university students need to be provided with education and training in these skills.

Most participant suggestions to raise sensitivity of university students towards peace actually point in the direction of human rights education that will be provided to university students. According to Harris (2004), peace education has become diversified and examines theoretical assumptions 
behind five different ways in which it is being carried out at the beginning of the twenty-first century: human rights education, international education, development education, environmental education and conflict resolution education. For this reason, it can be suggested that peace education can be achieved through human rights education programs aimed at positive behavior change in universities.

Activities organized in schools have a big role in peace education. The importance of curricular and extracurricular activities in human rights education has been emphasized in such international documents as the United Nations Recommendation Concerning Education for International Understanding, Co-operation and Peace and Education Relating to Human Rights Fundamental Freedoms dated 1974; the Resolution of Human Rights Education Decade dated 1993; and Council of Europe's Resolution on the Teaching of Human Rights dated 1978. It can be proposed that activities that are important for human rights education are just as important for peace education. Just as posited in international documents, participants have the aim to raise students who are sensitive toward peace when they become teachers in curricular and extracurricular activities through discussions, debates, and drama methods and through organizing trips, assigning research, inviting related people to school conferences, and showing films and documentaries.

\section{REFERENCES}

Aktan-Kerem, E and Kamaraj, I. (2007) Erken çocukluk döneminde barış değeri. Çoluk Çocuk Dergisi. 69, 30-33.

Alpkaya, G. (2001) Barış hakkı ve uluslar arası hukuk. Barış Hakkı ve Türkiye. Ankara, 13 Aralık.

Bloom, B. S. (1995). Insan nitelikleri ve okulda öğrenme. (Translation. D. A. Özçelik), Ankara: Milli Eğitim Basımevi.

Branson, M.S. and Torney, J. T. (1982) International Human Rights, Society and the Schools. Washington: National Council for the Social Studies Bulletin, No: 68.

Carter, C. C. (2004) Whither social studies? In pocketst of peace at school. Journal of Peace Education. 1: 1, 77-89.

Doğan, İ. (2002) Vatandaşlık, Demokrasi ve Insan Hakları. Ankara: PegemA Yayıncilık. 
Gözübüyük, Ş. (1993) Hukuka Giriş ve Hukukun Temel Kavramları. Ankara: Turhan Kitabevi.

Haavelsrud, M. (2004) Target: disarmament education. Journal of Peace Education. 1: 1, 37-59.

Harris, I. M. (2004) Peace education theory. Journal of Peace Education. 1: $1,5-21$.

Kaboğlu, İ. (1996) Dayanışma Hakları. Ankara: TODAİE İnsan Hakları Araştırma ve Derleme Merkezi Yayını.

Kapani, M. (1981) Kamu Hürriyetleri. A.Ü. Hukuk Fakültesi Yayınları, No: 453, Ankara.

Karaman-Kepenekci, Y. (2004) Öğrenci ve şiddet. Ankara Dergisi. 12-13.

Köylü, M. (2004) Peace education: An islamic approach. Journal of Peace Education. 1:1, 59-77.

Mansur-Sertel, J. (2007) Barış eğitimi: kuram ve sınıf deneyimim. Çoluk Çocuk Dergisi. 69, 34-36.

Oral, Z. (2007) Barış eğitimi. Çoluk Çocuk Dergisi. 69, 37.

Pembecioğlu-Öcel, N. (2007) Barışa giden yolda iletişim ve eğitim için tek koşul sevgi. Çoluk Çocuk Dergisi. 69, 38-42.

Reardon, B. A. (1988) Comprehensive Peace Education: Education for Global Responsibility. New York: Columbia University.

Sencer, M. (1986). Dünya barış yılı üzerine düşünceler. Insan Haklart Ylllı̆̆ı. Cilt: 8, 3-14.

Spence, R. and Makuwira, J. (2005) Do we make a difference? Teaching and researching peace at tertiary level. Journal of Peace Education. 2: 1, $17-33$.

Synott, J. (2005) Peace education as an educational paradigm: review of a changing field using an old measure. Journal of Peace Education. 2: 1, $3-17$.

Türkiye İnsan Hakları Kurumu Vakfı (2000) Tüm Insanlar... Insan Hakları Ĕgitimi İçin El Kitabı (Translation. M. Gülmez), Ankara: TİHAK, 2.

Türkiye İş Bankası Kültür Yayınları (1992) Atatürk ve Barış. Ankara.

Wintersteiner, W. (2004) The 'old Europe' and the new tasks for peace education. Journal of Peace Education. 1: 1, 89-103. 
